\title{
Survey pans university labs
}

\section{Tokyo}

TENS of thousands of professors and researchers at Japan's national universities have produced a damning assessment of the standard of research facilities in their institutions, in a survey just released by the Association of National Universities.

The survey comes at a time when Japan's principal science policy-making body, the Council of Science and Technology (CST), chaired by the Prime Minister, is debating problems in Japan's public-sector research environment. Given this timing, the survey will undoubtedly influence the council's recommendations later this year, which will determine Japan's public sector science policy for many years to come.

To assess the state of research in Japan's universities, the university association sent a questionnaire to 53,248 professors, associate professors, lecturers and research assistants at the country's 96 national universities in December last year. Of the 65 per cent $(34,325)$ who replied, about 85 per cent said that facilities in private-sector industrial research institutes were "much better" (60 per cent) or "slightly better" ( 25 per cent) than in their own universities. Similarly, they rated their universities poorly compared with private universities.

Many those working in science, engineering, medical, dental and pharmaceutical science departments complained that they have to use their own money to pay for domestic and international travel, books for their libraries and equipment, because funds from the Ministry of Education, Science and Culture (MESC), which is responsible for running the universities, are inadequate. The average personal outlay for these items each year was $¥ 570,000(\$ 4,200)$ in science, engineering and agriculture departments, and $¥ 870,000(\$ 6,400)$ in medical, dental and pharmaceutical science departments.

Seventy-five to eighty per cent of respondents said that analytical equipment, reagents and computer and information processing facilities are "totally inadequate" or "inadequate". In addition, funds for general expenses (such as telecommunication bills and salaries for assistants) were found to be twoand-a-half to four times less than necessary, and the number of competitive research grants available from MESC was called inadequate.

The survey should provide ammunition for those members of CST pushing for drastic reform of public-sector research and, in particular, the national universities. A subpanel of the council, which is composed of academics, industrialists and government officials, recently began hearings on a new set of recommendations that will set policy for the next five to ten years. (The last such recommendations were made in 1984 and were adopted by the cabinet in 1985).

Previous council recommendations have tended to be rather anaemic calls for improvement of basic research that have failed to get to grips with the problems in the national universities. One such problem, for instance, is that while CST is supposed to set policy for all the science-related ministries, its secretariat is located in the Science and Technology Agency (STA). As a result, the council tends to be regarded with suspicion by MESC, a bitter rival of STA, and in previous CST recommendations all references to national universities have been deleted at the request of MESC officials, who insist that such matters lie in the domain of the ministry's own science council.

But this time around, the pressure to do something (and to say something) about the universities is enormous. Japanese industry is becoming very concerned about the tendency of young Japanese to shun careers in science and engineering in favour of jobs in finance and economics. Industrialists and the Ministry of International Trade and Industry (MITI) say that unless something is done quickly to attract young people back to science and technology in the universities, Japan is headed for almost certain economic decline.

In the past, MITI has not paid much attention to CST deliberations. But this time a member of the ministry has been assigned full-time to work with the council in STA.

MESC is most unlikely to solve the problems on its own. One former senior official of Tokyo University points out that power (and budget) in MESC is concentrated in the sections that deal with high-school education, and that the sections that deal with research at the graduate level and above have comparatively little power to influence the ministry's policy and allocation of funds.

MESC officials dealing with research have tried to cope with this situation by expanding the budget for competitive grants while holding down general research funds that automatically go to all faculty. The intention is to cut off funds to those not actively involved in research.

Government officials outside MESC and the university researchers recently polled realize that it is probable that the only solution lies beyond the realms of MESC. Seventy-two per cent of respondents suggested that extra funds should be obtained from other ministries, 65 per cent suggested local governments, 68 per cent suggested private foundations funded by Japanese industry and 54 per cent suggested private industry itself.

MITI officials say that a foundation funded by Japanese industry and perhaps affiliated with STA, MITI and MESC might be an acceptable solution. But much depends on whether CST will finally decide to say something about Japan's universities when it issues its recommendations towards the end of this year.

David Swinbanks
JAPANESE TELEVISION

\section{New channel is lost in space}

Tokyo

A Combination of recent solar flare activity, the eccentric orbit of the Earth around the Sun, and a faulty solar panel seem likely to wipe out broadcasts of at least one of three new satellite television channels watched by millions of Japanese.

Japan's National Space Development Agency (NASDA) announced last week (10 April) that it expects difficulties with its new broadcasting satellite, Yuri-3a, launched last August. The satellite, which has defective solar panels, will be unable to sustain broadcasts of Japan's three channels between mid-May and midAugust.

The news must be particularly distressing for about 300,000 Japanese who have just paid $¥ 27,000$ ( $\$ 200$ ) for decoders plus $¥ 2,000$ a month to watch a new commercial satellite channel.

The 'WowWow' commercial channel began pay service at the beginning of this month. Before that, Japan Satellite Broadcasting Company (JSB), which operates WowWow, had broadcast unscrambled signals via Yuri-3a to attract subscribers.

NASDA officials blame the breakdown in part on what they call "unexpected" solar flare activity in March. Apparently, a shower of high-energy protons from the flares knocked out a few per cent of the panel's solar cells. And as the panels were already producing only about 75 per cent of their designed output (see Nature 347, 114; 1990), the additional loss was enough to reduce power below the minimum required for full services.

From mid-May to mid-August, the satellite will have enough power to broadcast on only two channels because during that period the Earth will be at its farthest point from the Sun in its elliptical orbit and also because the Earth's equatorial plane - in which Yuri-3a lies - will be at maximum inclination to the Sun. As a result, incidental sunlight on the satellite's solar panels will be less intense and the panels' power output will be reduced.

NASDA has suggested one possible solution. Yuri-3a's predecessor, Yuri-2b, which went out of service at the end of last year, could broadcast two channels for about a month before its fuel supply runs out. If JSB and NHK, the national broadcasting corporation that operates the other two channels, can agree to share the combined capacity of the two satellites, it may be possible for broadcasting services for the three channels to hobble along until another NHK broadcasting satellite (BS3H) due to be launched by a US Atlas rocket on Friday (19 April) comes into service at the end of May or the beginning of June. But NHK is reluctant to accept that idea until BS-3H is launched and fully tested.

David Swinbanks 